\title{
PELATIHAN MANAJEMEN PENGELOLAAN ADMINISTRASI MENGGUNAKAN METODE DEMONSTRASI DI WOTSOGO JATIROGO TUBAN
}

\author{
Ahmad Hariyadi, Masnuatul Hawa, Sutrimah, Siti Aniqoh Sofwani, Endah \\ Yuliani \\ IKIP PGRI Bojonegoro, STIE Semarang, Unipa Surabaya \\ e-mail: ahmadhariyadi86@gmail.com,masnuatulhawaufa@gmail.com, \\ sutrimahyusuf@yahoo.com, aniqoh2014@gmail.com, endahyuliani07@gmail.com5
}

\begin{abstract}
ABSTRAK
Pemerintahan Desa merupakan garda terdepan dalam penyelenggaran pemerintaban dan pelayanan publik di Indonesia. Hal itu bisa berjalan dengan baik kalau di dukung dengan SDM perangkat desa dan pemuda karang taruna yang mampu melaksanakan perannya dengan baik. Perangkat desa dan pemuda merupakan SDM di pemerintahan paling bawah yang memiliki andil besar terbadap pembangunan di negeri ini. Peran mereka dibutubkan terutama di desa sebagai penggerak pemerintahan desa. Kemampuan manajemen administrasi pemerintahan desa harus dikuasai oleh perangkat desa dan pemuda di suatu desa untuk memberikan pelayanan publik yang maksimal baik dari aspek tata kelola maupun dokumentasi. Tujuan kegiatan ini untuk memberikan pemahaman dan pelatiban terhadap manajemen pengelolaan administrasi Desa Wotsogo Kecamatan Jatirogo Kabupaten Tuban. Metode yang dipakai dalam pelatihan adalah metode Demonstrasi berbasis audio visual. Melalui metode Demonstrasi dibarapkan dapat melatih dan memahami manajemen administrasi pemerintahan. Sasaran pelatiban ini adalah perangkat desa dan unsur pemerintahan Desa Wotsogo Kecamatan Jatirogo.
\end{abstract}

Kata kunci: Pelatihan, Perangkat Desa, Pemuda, Demonstrasi

\begin{abstract}
Village apparatus is the front guard in the administration of government and public services in Indonesia. It needs to be supported by the human resources of the village, especially youth organization. Village apparatus and youth as the buman resources are at the bottom position of the government have many contributions in the development of the country. Their role is needed as the driving force in the village governance. The village apparatus and youth organization must capable in administration manajement to give good services to the public both in terms of administration and documentation. The purpose of this activity is to provide understanding and training on the administrative manajement of Wotsogo Village, Jatirogo District, Tuban Regency. The method used in the training is the audio-visual based demonstration method. Through the Demonstration method, it is hoped that it can train and understand the government administration manajement. The targets of this training are village apparatus and also the element of the Wotsogo Village government in Jatirogo District.
\end{abstract}

Keywords: Training, Village Apparatus, Youth, Demonstration 


\section{PENDAHULUAN}

Pemerintahan Desa merupakan garda terdepan dalam penyelenggaran pemerintahan dan pelayanan publik di Indonesia. ${ }^{1} \mathrm{Hal}$ itu bisa berjalan dengan baik kalau didukung dengan SDM perangkat desa dan pemuda karang taruna yang mampu melaksanakan perannya dengan baik. Perangkat desa dan pemuda merupakan SDM di pemerintahan paling bawah yang memiliki andil besar terhadap pembangunan di negeri ini. $^{2}$ Peran mereka dibutuhkan terutama di desa sebagai penggerak pemerintahan desa. ${ }^{3}$ Kemampuan manajemen administrasi pemerintahan desa harus dikuasai oleh perangkat desa dan pemuda di suatu desa untuk memberikan pelayanan publik yang maksimal baik dari aspek tata kelola maupun dokumentasi. ${ }^{4}$

Kondisi manajemen administrasi pemerintahan desa saat ini di Desa Wotsogo belum sepenuhnya menunjukkan manajemen yang sesuai dengan SOP yang telah dibuat oleh pemerintah. Manajemen administrasinya belum tertata dengan baik dari aspek tata kelola dan dokumentasi berkas. Peran IKIP PGRI Bojonegoro melalui kegiatan pengabdian masyarakat memiliki peran penting dalam meningkatkan sumber daya manusia termasuk perangkat desa dan pemuda agar mempunyai pemahaman dan pengetahuan terhadap manajemen pengelolaan administrasi Desa Wotsogo Kecamatan Jatirogo Kabupaten Tuban. Sesuai dengan visi dan misi dari IKIP PGRI Bojonegoro untuk melaksanakan tri dharma perguruan tinggi salah satunya pengabdian masyarakat maka kami ikut andil mengambil peran ini melalui kegiatan pelatihan.

Kemampuan perangkat desa dan pemuda dalam hal manajemen administrasi desa belum menunjukkan ketertiban administrasi yang sesuai dengan standar operasional pelaksanaan. Permasalahan yang terjadi manajemen administrasi desa masih belum tersusun dengan rapi dan pelaksanaannya hanya sekedarnya serta pendokumentasian administrasi belum dilakukan dengan baik. Perangkat desa dan

1 Rahardjo Adisasmita, Pembangunan Pedesaan dan Perkotaan (Yogyakarta: Graha Ilmu, 2006), 50.

2 Nurcholis Hanif, Pertumbuhan dan Penyelenggaraan Pemerintahan Desa (Jakarta: Erlangga, 2011), 70.

3 Darmuki dkk., "Pelatihan MC dan Protokoler Menggunakan Metode Drill Practice dengan Media Audio Visual pada Pemuda Karang Taruna," dalam Jurnal Abdimas, 3 (1), (2019). 11-12.

4 Dessler Gery, Manajemen Sumber Daya Manusia (Jakarta: Salemba Empat, 2017), 15. 
Pemuda belum memiliki pemahaman terhadap manajemen pengelolaan administrasi Desa Wotsogo Kecamatan Jatirogo Kabupaten Tuban. Pembekalan saat pelantikan perangkat dan sosialisasi/pelatihan manajemen administrasi yang pernah mereka ikuti masih bersifat teoritis, belum mengarah pada aplikatif.

\section{METODE}

Metode pelaksanaan kegiatan berupa tahapan atau langkah-langkah dalam melaksanakan pelatihan yang dimulai dari persiapan (penjadwalan), pelaksanaan, pelaporan. Adapun tahapan pelaksanaan program yaitu :

1. Persiapan

Adapun kegiatan-kegiatan yang akan dilakukan dalam tahap persiapan yaitu :

a) Survei tempat pelaksanaan kegiatan.

b) Pembuatan proposal dan penyalesaian administrasi perijinan tempat atau lokasi pengabdian masyarakat.

c) Pembuatan modul pembelajaran.

d) Menyiapkan dan melengkapi peralatan dan perlengkapan.

2. Pelaksanaa kegiatan

Kegiatan PKM ini, memiliki beberapa konsep dalam pembelajaran dan pembekalan materi terhadap beberapa pengetahuan manajemen administrasi desa agar dapat menerapkan dalam dunia kerja dan pelayanan kepada masyarakat.

Tabel 2

Pelaksanaan Kegiatan

\begin{tabular}{|c|l|l|l|l|}
\hline Pertemuan & Materi Ajar & Waktu & Alat/bahan/sumber & Penilaian \\
\hline \multirow{2}{*}{ Ke-1 } & $\begin{array}{l}\text { Perkenalan } \\
\text { Berisi Game- } \\
\text { game tentang } \\
\text { perkenalan dan } \\
\text { observasi awal } \\
\text { peserta }\end{array}$ & 60 & Video, Proyektor, & $\begin{array}{l}\text { Keaktifan, } \\
\text { inovatif, } \\
\text { kognitif. }\end{array}$ \\
\hline Ke-2 & Materi 1 & 120 & Video, Proyektor, & Keaktifan, \\
\hline
\end{tabular}


Indonesian Engagement Journal

Vol. 2 No. 1 Juni 2021

\begin{tabular}{|c|c|c|c|c|}
\hline & $\begin{array}{l}\text { Pengertian } \\
\text { Manajemen } \\
\text { administrasi } \\
\text { desa }\end{array}$ & menit & Praktek Lapangan & $\begin{array}{l}\text { inovatif, } \\
\text { kognitif. }\end{array}$ \\
\hline $\mathrm{Ke}-3$ & $\begin{array}{l}\text { Materi } 2 \\
\text { Demonstrasi } \\
\text { manajemen } \\
\text { administrasi } \\
\text { desa }\end{array}$ & $\begin{array}{l}120 \\
\text { menit }\end{array}$ & $\begin{array}{l}\text { Video, Proyektor, } \\
\text { Praktek Lapangan, }\end{array}$ & $\begin{array}{l}\text { Keaktifan, } \\
\text { inovatif, } \\
\text { kognitif. }\end{array}$ \\
\hline $\mathrm{Ke}-4$ & $\begin{array}{l}\text { Materi } 3 \\
\text { Publik Speaking } \\
\text { bagian dari } \\
\text { manajemen } \\
\text { pelayanan } \\
\text { publik }\end{array}$ & $\begin{array}{l}120 \\
\text { menit }\end{array}$ & Video, Proyektor, & $\begin{array}{l}\text { Keaktifan, } \\
\text { inovatif, } \\
\text { kognitif. }\end{array}$ \\
\hline Ke-5 & $\begin{array}{l}\text { Evaluasi dan } \\
\text { rencana tindak } \\
\text { lanjut. }\end{array}$ & $\begin{array}{l}30 \\
\text { menit }\end{array}$ & Praktek Lapangan, & $\begin{array}{l}\text { Keaktifan, } \\
\text { inovatif, } \\
\text { kognitif. }\end{array}$ \\
\hline
\end{tabular}

3. Evaluasi.

Evaluasi ini bertujuan untuk melihat sejauh mana perkembangan program yang dilaksanakan, untuk mengetahui kendala-kendala apa saja yang ada, permasalahan-permasalahan yang ada. Untuk mengetahui cara-cara yang dilakukan untuk menanganinya sehingga program pengabdian ini dilakukan dengan dan benarbenar efektif dan juga maksimal. Evaluasi yang terakhir yaitu berupa demonstrasi.

4. Pembuatan laporan.

a. Pembuatan Laporan Awal

Pembuatan laporan awal disesaikan dengan hasil yang telah dicapai selama kurang lebih saat pembinaan terhadap pemuda karang taruna.

b. Revisi Laporan 


\section{Indonesian Engagement Journal}

Vol. 2 No. 1 Juni 2021

Revisi dilakukan apabila adanya kesalahan pada pembuatan laporan.

c. Pembuatan Laporan Akhir

Pembuatan laporan akhir dilakukan saat setelah adanya revisi, diharapkan agar laporan akhir penyusunananya diperoleh hasil yang baik.

Sedangkan pelaksanaan pelatihan manajemen administrasi desa yang berkualitas sebagai berikut:

1. Menyampaikan materi mengenai manajemen administrasi desa menggunakan media audio visual

2. Pelatihan publik speaking untuk meningkatkan pelayanan publik

3. Demonstrasi manajemen administrasi dan pelayanan publik

\section{ANALISIS DAN PEMBAHASAN}

Kegiatan PKM pelatihan manajemen pengelolaan administrasi bagi perangkat Desa Wotsogo Kecamatan Jatirogo Kabupaten Tuban secara umum berjalan dengan baik. PKM ini dilaksanakan selama dua hari tanggal 9-10 Nopember 2019. Hari pertama program dilaksanakan di pendopo balai Desa Wotsogo dengan penyampaian materi tentang manajemen pengelolaan desa sekaligus pembukaan tim PKM oleh Kepala Desa. Berikut gambar kegiatan pembukaan PKM di Desa Wotsogo Kecamatan Jatirogo Kabupaten Tuban.

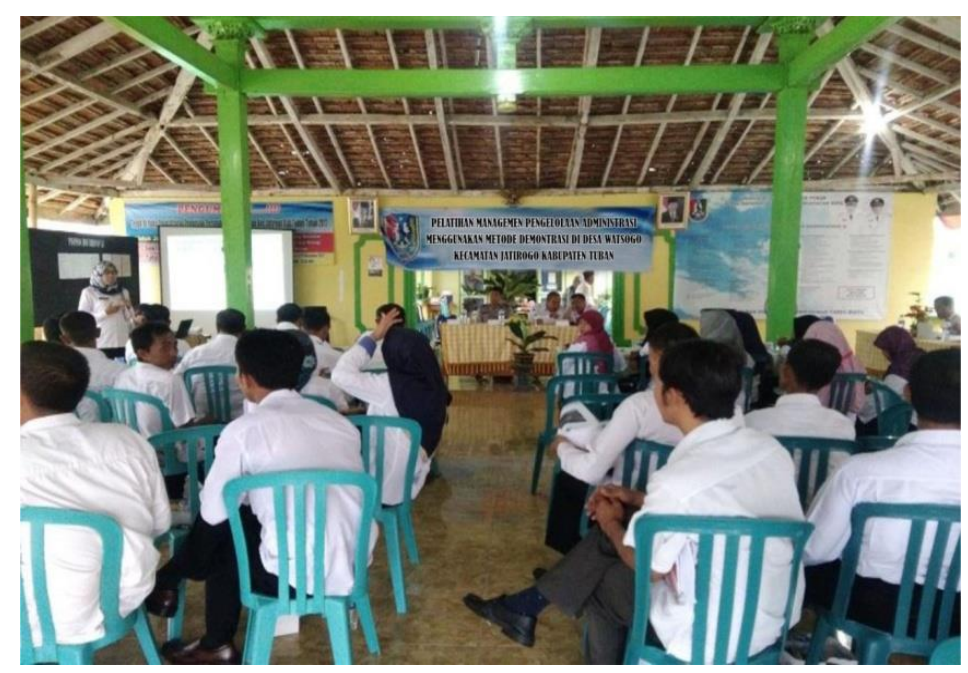

Pada hari kedua dilaksanakan di ruang pertemuan PKK Desa Wotsogo Kecamatan Jatirogo Kabupaten Tuban dengan agenda aplikasi dari materi hari 


\section{Indonesian Engagement Journal}

Vol. 2 No. 1 Juni 2021

pertama tentang manajemen administrasi pemerintahan desa. Pengelolaan administrasi di Desa wotsogo berdasarkan observasi awal sebelum pelatihan PKM ini menunjukkan belum tertata dengan baik, hal ini berdasarkan surat masuk dan surat keluar masih campur menjadi satu pembukuan. Selain itu hasil wawancara awal mengenai buku tamu belum tersedia dan belum pernah dibuat. Hal ini mengindikasikan bahwa manajemen pengelolaan administrasi desa belum berjalan sesuai dengan standar tata kelola administrasi desa. Selain itu alur pelayanan publik desa belum memberikan informasi kepada masyarakat kepengurusannya prosedurnya harus seperti apa.

Setelah kegiatan pelatihan manajemen administrasi pemerintahan desa dilaksanakan oleh tim PKM hasilnya menunjukkan respon yang positif. Hal ini terlihat dari partisipasi perangkat desa yang hadir pada saat pelatihan hari pertama maupun hari kedua. Peserta pelatihan hadir 100\% sesuai dengan undangan yang dibagi. Mereka mengikuti kegiatan pelatihan dengan antusiasme ketika tim PKM memberikan materi manajemen administrasi pemerintahan desa menggunakan media audio visual. Mereka memperhatikan dengan seksama materi yang disampaikan tim PKM dan beberapa orang bertanya mengenai administrasi apa saja yang perlu ada dalam manajemen administrasi pemerintahan desa. Mereka juga puas dengan jawaban yang diberikan oleh tim PKM membuat mereka memperoleh ilmu baru mengenai administrasi desa.

Pelatihan diakhiri dengan demonstrasi/simulasi (praktik manajemen administrasi pemerintahan desa) yang dilakukan oleh para peserta pelatihan. Masingmasing peserta dipersilahkan simulasi manajemen administrasi pemerintahan desa dalam hal pelayanan publik. Peserta langsung mengaplikasikan berbagai materi yang telah disampaikan pemateri tentang manajemen administrasi pemerintahan desa. Simulasi peserta sebagai petugas dievaluasi bersama- sama oleh pemateri dengan menerima masukan dari peserta yang lain. Simulasi yang dilakukan oleh peserta pelatihan setelah menerima materi, terlihat bahwa keterampilan dan kemampuan mereka dalam manajemen administrasi pemerintahan desa mengalami perbaikan jika dilihat dari berbagai aspek manajemen administrasi pemerintahan desa. Berikut hasil simulasi manajemen administrasi pemerintahan desa yang dilaksanakan peserta pelatihan saat pretes maupun postes. 
Tabel 2

Rekap Hasil Simulasi manajemen administrasi pemerintahan desa

\begin{tabular}{ccc}
\hline Indikator & $\begin{array}{c}\text { Nilai } \\
\text { Rata-Rata } \\
\text { Pretes }\end{array}$ & $\begin{array}{c}\text { Nilai } \\
\text { Rata-Rata Postes }\end{array}$ \\
\hline Sikap pelayanan publik & $31,25 \%$ & $75 \%$ \\
\hline Kelengkapan administrasi surat & $18,75 \%$ & $81,25 \%$ \\
\hline Alur unit pelayanan administrasi & $37,5 \%$ & $81,25 \%$ \\
\hline Adanya buku dokumentasi & $50 \%$ & $87,5 \%$ \\
pelayanan & & 68,75 \\
\hline Adanya informasi persyaratan & $31,25 \%$ & \\
kepengurusan dokumen & & \\
\hline
\end{tabular}

Berdasarkan hasil postes di atas menunjukkan bahwa penggunaan metode demonstrasi dengan media audio visual dapat meningkatkan keterampilan peserta pelatihan manajemen administrasi pemerintahan desa. Peningkatan keterampilan peserta pelatihan dapat dilihat dari hasil postes nilai rata-rata penggunaan sikap pelayanan peserta pelatihan sebanyak 12 orang atau $75 \%$, dari kelengkapan administrasi surat menyurat sebanyak 13 orang atau $81,25 \%$, peserta pelatihan memiliki alur unit pelayanan administrasi sebanyak 13 orang atau 81,25\%, dari aspek adanya buku dokumentasi pelayanan sebanyak 14 orang atau 87,5\%, kemudian dari aspek adanya informasi persyaratan kepengurusan dokumen sebanyak 11 orang atau $68,75 \%$.

Pada awal pelatihan manajemen administrasi pemerintahan desa, tim Pengabdian memberikan soal pretes untuk mengetahui pengetahuan mengenai MC dan protokoler peserta pelatihan. Setelah tim menyampaikan materi dan telah melakukan praktik sebagai MC satu persatu tim pengabdian memberikan postes kepada peserta untuk mengetahui tingkat keberhasilan pengabdian yang dilakukan oleh tim terkait pengetahuan dan pemahaman sebagai manajemen administrasi 
pemerintahan desa. Soal postes yang diberikan kepada peserta pelatihan sama dengan soal pada pretes. Hasil pretes dan postes pada pelatihan manajemen administrasi pemerintahan desa dapat digambarkan pada tabel berikut.

Tabel 3.

Rekap Hasil Pretes dan Postes

\begin{tabular}{ccc}
\hline Indikator & $\begin{array}{c}\text { Nilai } \\
\text { Pretes }\end{array}$ & Nilai Postes \\
\hline $\begin{array}{c}\text { Apakah anda memiliki pengetahuan } \\
\text { manajemen administrasi pemerintahan } \\
\text { desa }\end{array}$ & $18,75 \%$ & $93,75 \%$ \\
\hline $\begin{array}{c}\text { Bisa mempraktikkan manajemen } \\
\text { administrasi pemerintahan desa }\end{array}$ & $24,10 \%$ & $100 \%$ \\
\hline $\begin{array}{c}\text { Apakah anda memiliki skill manajemen } \\
\text { administrasi pemerintahan desa }\end{array}$ & $24,10 \%$ & $93,75 \%$ \\
\hline $\begin{array}{c}\text { Apakah anda memiliki sikap seorang } \\
\text { pelayan publik }\end{array}$ & $62,50 \%$ & $81,25 \%$ \\
\hline $\begin{array}{c}\text { Apakah anda memiliki kepercayaan diri } \\
\text { ketika menjadi petugas pelayanan publik }\end{array}$ & $50 \%$ & $87,5 \%$ \\
\hline
\end{tabular}

Hasil postes menunjukkan bahwa peserta pelatihan memiliki pengetahuan sebagai manajemen administrasi pemerintahan desa sebanyak 15 orang atau 93,75\%, dapat mempraktikkan sebagai manajemen administrasi pemerintahan desa sebanyak 16 orang atau $100 \%$, memiliki skill sebagai manajemen administrasi pemerintahan desa menurut 15 orang atau 93,75\%, memiliki sikap seorang pelayanan publik sebanyak 13 orang atau 81,25\%, dan peserta memiliki kepercayaan diri ketika menjadi petugas pelayanan publik sebanyak 14 orang atau 87,5\%. Secara umum kegiatan PKM Pelatihan manajemen administrasi pemerintahan desa pada perangkat desa menggunakan metode demonstrasi berjalan dengan baik dan dapat menumbuhkan kepercayaan diri, kesadaran, menambah pengetahuan dan pemahaman tentang kegiatan manajemen administrasi pemerintahan desa. 


\section{KESIMPULAN}

Kegiatan PKM ini secara keseluruhan direspon positif oleh peserta yaitu perangkat Desa Wotsogo Kecamatan Jatirogo Kabupaten Tuban. Pelatihan manajemen ini diikuti oleh seluruh perangkat dan unsur pimpinan BPD, dan LPMD. Tujuan akhir dari pelatihan ini untuk memberikan kemampuan manajemen administrasi kepada perangkat desa dan unsur pimpinan lembaga desa. Sebagian besar perangkat Desa Wotsogo sudah memiliki kemampuan administrasi setelah memperoleh pelatihan ini. Kemampuan manajemen administrasi ini akan meningkatkan kinerja pelayanan kepada masyarakat dan meningkatkan kemampuan perangkat dalam mendokumentasikan arsip atau pengadministrasian di desa.

\section{DAFTAR PUSTAKA}

Adisasmita, Rahardjo. (2006), Pembangunan Pedesaan dan Perkotaan.Yogyakarta, Graha Ilmu.

Darmuki, A., M. Sholehuddin, Nur Alfin Hidayati, Sutrimah. (2019), "Pelatihan MC dan Protokoler Menggunakan Metode Drill Practice dengan Media Audio Visual pada Pemuda Karang Taruna," Jurnal Abdimas. 3 (1).

Dessler, Gery. (2017), Manajemen Sumber Daya Manusia, Jakarta: Salemba Empat.

Nurcholis, Hanif. (2011), Pertumbuhan dan Penyelenggaraan Pemerintahan Desa. Jakarta: Erlangga. 